\title{
Are the Structural Holes a Form of Social Capital? A Theoretical Debate
}

\author{
Agustinus Rusdianto Berto \\ Department of Communication Science, \\ FISIP, Universitas Indonesia \\ Jakarta, Indonesia \\ arus.berto@gmail.com
}

\author{
Ilya Revianti Sudjono Sunarwinadi \\ Department of Communication Science \\ FISIP, Universitas Indonesia \\ Jakarta, Indonesia \\ ilya.revianti@gmail.com
}

\begin{abstract}
Social capital plays a significant role in utilizing the flow of information. Generally, social capital can be generated by establishing a close relationship between many people in order to create mutual trust. However the structural holes theory instead sees otherwise, high social capital can only be obtained through a sparse relationship. Based on that theoretical perspective, this paper aims to describe and elaborate these two opposing views. Therefore, the author conducted a literature review of nine previous studies. This paper concludes that the structural holes theory is also a form of social capital. Furthermore, this theory is interdependent and complementary to the theory of network closure. The intermediary must combine weak ties with strong ties simultaneously to gain maximum benefits of information and control. He/she should reach out various kinds of relationships between others different groups to generate diverse information (nonredundant) that used to create a good idea. At the same time, the intermediary also needs to maintain and/or enhance the strength of trust or closure in the existing ties in order to distribute the idea because it potentially can increase the adoption of the idea. That collaboration can be used to improve the performance of public services by applying them to internal communication audits and autonomous external surveillance mechanisms.
\end{abstract}

Keywords-social capital; structural holes; closure network; strength of weak ties; public services

\section{INTRODUCTION}

Today we live in an era of information flooding. Alvin Toffler (1980) emphasizes the importance of information as the most economic resource or rawmaterial because it will never run out, unlike other resources which are mostly limited or scarce. He has identified present condition and termed it as 'the third wave'. In addittion, McLuhan (1964) has predicted the raise of information flow and proposed the concept of 'global village'. Long before that, Fritz Machlup (1962) the economist has estimated the trend of economic structural shifting in the United States (US) from industrial to information society (Dahlan, 1997). Departing from the conception of Shannon and Weaver (1949), information can be defined as an uncertainty where there is an option out of a group of alternative options in decision making. The situation can be reduced by redundancy, that is by repeating or duplicating information to every party taking part in communication to reduce the uncertainty and noice in the channel (Rogers, 1997). This redundancy of information is utilized by information intermediaries to control the information flow in order to create an uncertainty among the member of communication network.

That redundancy of information can be managed to be more profitable using social capital, a skills to overcome the overload or the lack of information flow to transform into economic investments. It can help an individual turning human capital and financial capital - without even owning them - into personal benefits by harnessing the holes in information network. In other words, the individual acts as an information broker or intermediary by creating network holes by way of disconnecting the flow of information among people communicating with him in a communication network (Monge \& Contractor, 2003, p. 143). But today, because of the advancement of technology, everyone can be an intermediary. The role of social capital becomes very significant, because everyone can build relations easily through technologies (such as cellular phones), especially when an intermediary faces a competition. Since connectivity has been something natural and compulsory for the stakeholders of the network, the intermediaries have to acquire a social capital in order to win the fast and congested competition of industry.

Burt (1995) suggests that when an information intermediary enters the competition, he is likely to bring at least three capitals. First, financial capital fresh cash in the pocket or bank, investment, or credits. Second, human capital - their natural quality (appeal, health, intelligence, and face or looks) combined with skills they get from formal education and working experience, which make them more agile in fulfilling certain duties. Third, social capital - connection with other actors (friends, colleagues, and other contacts) who can give them opportunity to use their human and financial capital. In an industry, individuals who have human and financial capital are usually those who are able to improve the quality of products. Whereas people possessing social capital are those 
who are able to communicate the quality of the product to consumer, or other stakeholders of industry. People like this are usually called 'the rainmaker' because they are good at negotiating with clients and creating business deals that bring in profits, income, or fundings for an organization.

Social capital is significantly different from human capitals (cultural capital and symbolic capital) and financial capital (economic capital). First, human and financial capital are the kind of properties or wealth possessed individually, either wholly or partly. Whereas social capital is something that is owned together by parties in a relation - no one can have it exclusively. Second, linked to the equation of market production, human and financial capital emphasize on investment related to the forming of production capability of a product before it is launched to the market. Financial capital is required to get raw materials and production facilities, whereas human capital is needed to craft the raw materials into competitive products. Meanwhile, social capital concerns rate of return which is gained from the relation with colleagues, friends, and clients, so it is able to convert human and financial capital into profits for the company. Thus, social capital becomes the last referee in deciding who is succesful in the competition (Burt, 1995).

Yet in practice, social capital is not always measured by how much closeness we have in a relationship with someone we know, as many sociologist have pointed out (like Bourdieu, 1979; Coleman \& Hoffer, 1987; Bourdieu \& Wacquan, 1992; Putnam, 1993; Coleman, 1998; Woolcook, 2001). In the opposite view, structural holes theory argue against that explanation. According to the theory, social capital can be formed by exploiting disconnected relationship between parties who tend to be less familiar with each other, and it will form information holes (or gaps) among the relationships. It means, when the intermediary successfully do that, actually he/she can control the flow of information that needed by people who involved in the relationship. The intermediary who get information benefit from that conditions is called tertius gaudens, or 'the laughing third' (Burt, 1995). Because of its exploitative nature, this theory is often considered not to be part of the theory of social capital because intermediary have a low level of trust. This paper attempts to explain the conditions by reviewing theoretical debates and criticisms of structural holes theory.

\section{LITERATURE REVIEW AND DISCUSSION}

\section{A. Structural Holes Conditions}

This theory studies the advantage of nonredundant relationship in communication network. Structural holes act as a buffer formed by the disengagement of non-redundant contacts. Ronald S. Burt (1992) introduced this theory by explaining that an actor (A) is able to condition so that people on his network (B and C) are unable to get any information anywhere except the actor himself as the main source of information.

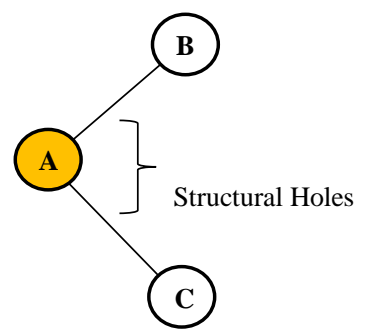

Fig. 1. A Simple Illustration of Structural Holes Theory

This triadic - or more - relationship of information make people demanding information become dependent to the actor, so that he could benefit from the ignorance of those people and make it his social capital to dominate people. Eventually he will be the one who rules as an intermediary that bridges. In sum, the actor acts as tertius gaudens, a third party who gets benefit out of the relationship of people whom he exploits. Burt (1992) calls it 'between two fighters, the third benefits,' or 'between two fighters, the third laughs'; whereas Simmel (1995) abbreviates it as 'the third who benefits' (Monge \& Contractor, 2003, p. 143).

Tertius gaudens applies information management strategy when facing two situations. First, when there is a competition among several parties in obtaining the same information. It is a very beneficial situation, though, in that one is able to give the information to any party who bids the highest price, so that in the end there will be parties who get information (win) and there will be those who do not get information (lose). Second, when a conflict occurs among parties demanding different information. Here tertius acts as a mediator trying to compromise in order to find resolution for all the warring sides. Though the information demanded might be different, tertius will be able to get these following information benefits: (1) access, by getting information that no one else understands and selecting them to avoid information overload (Dutton, 1999); (2) timing, by building relations with the right individuals to be given information earlier; and (3) referrals, by exchanging information with other parties outside the communication network (Monge \& Contractor, 2003 , p. 144). Basically, the explanation above illustrates control benefits in structural holes. By being the first to know, one is able to decide when and to whom the information will be given next. The contact selection is mostly determined by trust invested to others, either to whom one knows 
directly, or whom one knows through other people (Burt, 1995).

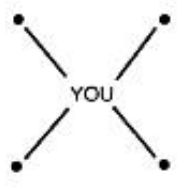

Network A'

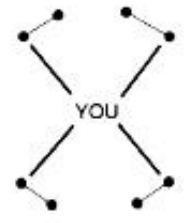

Network B:

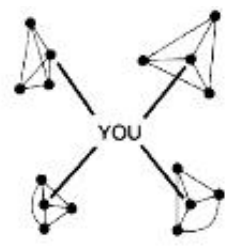

Network C
Fig. 2. Strategic Network Expansion of Structural Holes Theory (Burt, 1995)

To increase the benefit, structural holes need to expand network in accordance with the strategies of optimization. First, efficiency, by adding new non-redundant contacts. New contacts directly connected with the source of information are called primary contact, whereas new contacts indirectly connected with the source - mediated by the primary contact - are secondary contacts. The adding of new contacts will consume time and money, thus it is important to choose the right and trustful primary contacts because they are those who will spend much time and money to maintain connection with secondary contacts. Second, effectivity, by severing the primary contacts from their secondary, in order to be more focused in managing resources on the primary contacts. Instead of managing all of the contacts alone, the structural holes delegate the maintaining of the secondary contacts to the primaries connected directly with the source of information, so that individuals around the source are able to focus solely on their primary contacts and widen their networks by adding new clusters. If the principle of efficiency emphasizes on the average of people connected to one primary contact, the principle of effectivity is more focused on the number of people connected with all primary contacts (Burt, 1995).

In general, this theory suggests that redundancy indicates the absence of structural holes. Redundancy can occur either by cohesion or by the presence of structural equivalence. When both of them are absent in a network, structural holes are formed (Burt, 1995). By cohesion, contacts are strongly connected, indicating the absence of structural holes, e.g. the relationship between father and son, brother and sister, husband and wife, close friends, people who have been partners for a long time, people who frequently get together for social occasions, and so on. Those who establish mutual contacts will be easily accessed. Structural equivalence occurs when one has the same source of information with others, which will so likely to be redundant because they establish contacts with the same people. People who spend more time together tend to know each other better. This structural equivalency relationship is the cornerstone to direct contact (cohesion). When one has connected with whom he has something in common in a network (redundancy), he is also able to connect with different people outside his network (non-redundancy) because of the structural equivalence. But if they often meet and feel close to one another, they tend to communicate more frequently and probably have mutual contacts. The structural holes give non-redundant benefits to many parties involved. If these two conditions occur simultaneously, then it is most likely that redundancy will happen through cohesion.

In 'Structural Holes and Good Idea,' Burt (2004) conducted an examination of structural holes theory extensively to 637 managers in a network of the biggest electronic company in the United States. The study shows that the managers group based on division. From 514 links (edge) or connection between managers, most of it $(62$ percent) are done within the same business units or divisions, 178 connections (35 percent) are done with head manager, and a only small fraction (3 percent) of the managers build contact with other units or divisions. Burt suggests that the managers who build contacts with other manager from another division put themselves in structural holes because they act as intermediaries or brokers among managers. The main finding of this study is that new ideas for the improvement of the company (good ideas) are likely to come from the typical of broker managers, compared to those who only make contacts with managers from the same division. Manager who positions himself as broker understands the condition and the information of other units, and produces the best ideas for advancement of the company. Generally, managers who only maintain contact with colleagues from the same unit only discuss internal problems. They are incapable of thinking out of the box because they are only buzy dealing with daily technical problems of their own business units, so that they do not understand the condition of other units or divisions. Therefore, a person who is in structural holes tend to be more skillful in managing information compared to those who is not.

\section{B. Criticism of Structural Holes: Network Closure}

Information intermediaries occupy several unique positions when communicating with other parties in a communication network. Beside in structural holes, actors performing as information intermediary can also be positioned in network closure when they are on the same group (ingroup), or in the position of 'the strength of weak ties' when they are in different clusters (outgroup). The difference of position also collides their pattern of control when they are acting as information intermediaries intervening other parties. Gould \& Fernandez (1994) define information intermediary 
or brokers as a relation where one actor mediates the source and the flow of information between two or more disconnected actors. They propose five kinds of brokers in a communication network: (1) coordinator, intermediaries from the same group with other mediated actors; (2) gatekeeper, intermediaries who actively act as the filter of information from outside that flow to their groups; (3) consultant or itinerant broker, intermediaries belonging to different group from actors whom he mediates; (4) representative, intermediaries representing one side and communicate with other parties or actors, when one or more members of the groups ask an actor to represent the group to communicate with outsiders; and (5) liaison, intermediaries coming from different groups, who mediate with actors also coming from different groups.

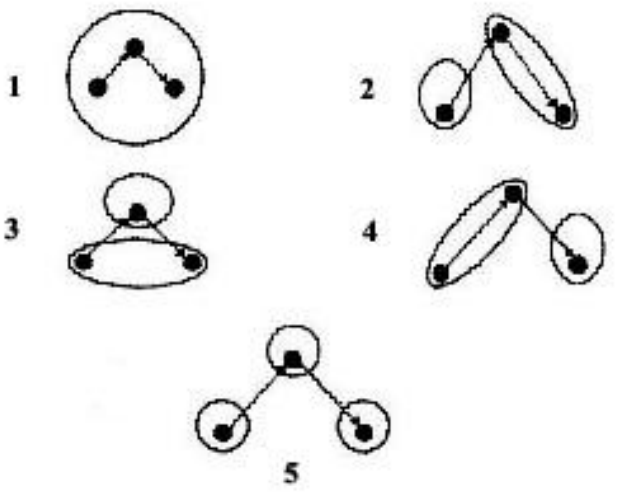

Fig. 3. Five Types of Brokerage Relations (Gould \& Fernandez, 1994)

The argument of structural holes theory is critisized by Coleman (1998) who proposed network closure theory. Closed network is signed by the cohesiveness among contacts. He firmly states that an actor is more advantageous if he is on a closed network because, in his conception, Coleman argues that network is a social capital which can be benefited by actors (people, institution, company) to maximize profits in a social structure. The more the member, the more dense, and the more closed the network, the better it will be. In contrast, an open network is signed by the lack of cohesiveness, connection among contacts is very inconsiderable and minimal. Since structural holes is in an open network, it shows the lack of social capital possessed by an actor. Basically, the good social capital is signed by the presence of trust and acceptance for other people or actors. The more intense the relation and interaction, the more trust harvested. These following arguments will illustrate the advantage of the closed-network: (1) to foster responsibilities and trustworthiness; (2) it is more likely to obtain information from numerous sources, so the information could be more trusted because the validity could be verified by other sources; and (3) the member of the network obey norms, so actors acting not in accordance with it could be punished by the member of the network.

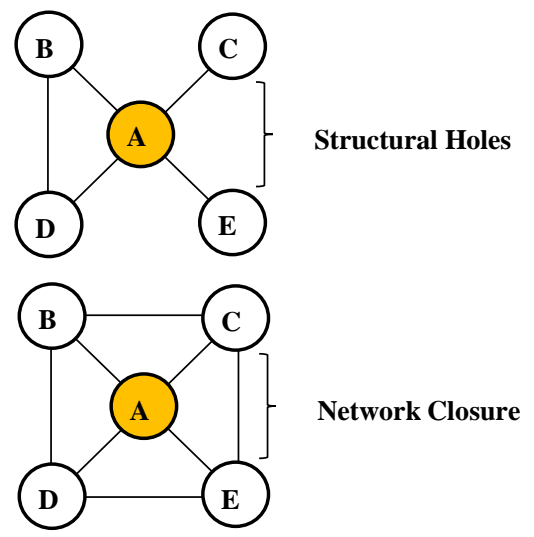

Fig. 4. A Simple Comparison between Structural Holes and Network Closure (Eriyanto, 2014)

A study conducted by Coleman \& Hoffer (1987) to 4,000 middle-school drop-outs in the United States found that the lower rate of drop-out belongs to those who have strong social capital, indicated by the presence of both parents (father-mother). Time allocated by the parents to build relationship with their children is proven to lessen the number of drop-out. The most intense relations are found in Catholic schools because they often hold parents meeting. The cordial relation (or social capital) shows the network closure of the family. Furthermore, having financial and human capital cannot assure one to stay at school. Rather, the drop-out rate among those who own the two capitals tend to be higher (Eriyanto, 2014).

In another situation, structural holes are not always advantageous. The research of Melisa Arisanty (2014) about the reconcilliation process of Balunuraga conflict in South Lampung, found that, rather, one who acts as mediator or intermediary (ego) tries to reduce (or even eliminate) the structural holes (structural non-holes) to increase the possibility of the conflicting people to get to know each other, so it will raise the probability of reaching the same goal, namely peace. It means that structural holes are concidered as hindrances for conflict resolution, in that it requires cohesiveness (network closure). But one must not forget that the position of intermediary in structural holes still can be beneficial because it functions as a bridge connecting information between two conflicting parties, as well as being a brokerrepresentative serving the interest of the two irresolute parties and the government. Thus, ego sends persuasive messages, such as the philosophy of life of each ethnicity, the using of modest sentences or language so it will give freedom for people to choose, and appreciate parties that help to 
create peace. Thus, eventhough structural holes are considered disadvantageous for conflict resolution, one in structural holes will keep trying to maintain one's position in order to acquire positive image, self-existency, and the strengthening of one's group or ethnicity in the future. It is still in line with the assumption of structural holes theory that ego will keep trying to maintain its position as structural holes in order to gain profits as much as possible.

In the study of communication technology, Irwansyah (2010) conducted a research about the network structure of family communication based on cellular phone (cellphone) to 104 people of Boro, originated from Desa Pule, Wonogiri Regency, who live in the vicinity of Jakarta, Bogor, Depok, Tangerang, and Bekasi. The finding of this research rejects the supposition of structural holes theory saying that structural holes in communication network can stimulate economic competition. Instead, the position and relation between cellphone users are coordinative and integrative, and able to accommodate and coordinate various interests in the network. Cellphone is able to strengthen personal, social, and kinship communication network. When away from home, one needs social support from family, either those related biologically or psychologically. Network capital is an ability to to use the network of communication technology to build contact (kinship and frequency) in social network and make it useful for social life. This network capital is owned by agents or brokers who find a solution for long-lasting social interests, not only solution for ephemeral economic interest or conflict resolution. Brokers utilize cellphone to affiliate, coordinate, mobilize, and confirm fastly, without limited by time, space, and distance. Nevertheless, cellular phone help broker to get profits from a structural holes.

In organizational level, the position of structural holes is not always deterministic in shaping the performance of a company. The study of Liao \& Phan (2015) to 191 technology company in the United States found that: (1) the higher the firm's ability to acquire well-developed knowledge (patent), the lesser the rate of knowledge creation in structural holes; (2) the capability of the firm to integrate a knowledge affects the creation of knowledge and its structural holes; and (3) the more diverse technology possesed by the company, the higher the activity of knowledge creating and its structural holes. Firms in structural holes can indeed potentially increase its level of knowledge creation, although they will not keep producing excellent innovations. Firms that do not have compatible capability (to acquire knowledge and diverse technology), are unable to gain profits. The firm's capability to mobilize and exploit resources will determine the position of structural holes in external network or alliance with other companies
(Liao \& Phan, 2015, pp. 15-18). This research concludes the importance of the domination over knowledge or information (e.g. patent) in determining the firm's position in structural holes in competition to gain profits.

Meanwhile, concerning the network of industry, Ying, Norman \& Zhou (2014) conducted a study to 745 websites of tourism organization and company in Charleston (US) and found that a small fraction of local Destination Marketing Organization (DMO) websites position themselves in structural holes (central), so they act as brokers or hubs controlling the flow of tourism information. These brokers decrease the density and connectivity rate of the network. The control over the flow of information is practiced by providing hyperlinks to the core and peripheral websites of tourism. It is interesting that the core-tourism websites having the same characteristic (homophile) are rather low in connectivity (e.g. those which offers information such accommodation, food and beverage, recreational operator, entertainment or attraction, and tourism intermediaries) than the peripheraltourism websites (e.g. educational institution, transportation, and government institution). The high level of competition among the core sectors of tourism that have the same business line makes them reluctant to make contact with their own peers because they regard them as competitors. They tend to make hypelinks to the websites of organization or institution that are not on the same business line in order to complement their products or services (complementary). On the other hand, peripheral tourism websites build cordial connections with their communities (wheter with their supporting peers or the core) to exchange information.

Cao \& Tian (2015) also found the same tendency in the network of economic tourism industry in Xinjiang province, China. Though the structural density of the whole network is not so low (somewhat enough), there are still economic inequality between the Northern and Southern region. The Northern region tend to be more dense economically because they have the higher level of tourism, high-quality tourism resources, infrastructures, and favorable geographical location (Cao \& Tian, 2015, p. 133).

The research of communication network done by Aini Kurniati (1998) to the member of Banjar in the tourism region of Bali also found the similiar thing. The network of communication formed between the member of Banjar tend to be weak. Many of the network member only mingle with their own Banjar friend, instead of newcomers or immigrants. The weakness of the communication network is influenced by the amout of time spent to build connections, emotional intesity, mutual trust among dyadic partners, or reciprocity (feedbacks) from dyadic options. The research proves that 
factors such closeness and likeness (culture, age, education, amount of salary, organization or community, and kinship) are not always able to make the network dense/close/strong (Kurniati, 1998). Those previous studies show that in order to maximize the benefit of information in the network, one should have two position: (1) structural holes position (tertius gaudens); and (2) closure network position.

\section{The Strength of Weak Ties as a Compromise}

Relevant to that, Mark Granovetter (1973) proposes 'the strength of weak ties' theory when analyzing the network structure of job-seeking information. The research found that, rather, most of the job information is obtained from personal contacts who live apart and meet accidentally at particular events, such as school friends. They practically have never got job information from their closest contacts. It shows that the relation could tie strongly due to the intensive communication among contacts, or could tie weakly due to the lack of communication among contacts. The strength of the tie could be measured by four indicators. First, time, how much time spent to interact with contacts. The longer the interaction, the stronger the relationship. Oppositely, the more brief the interaction, the weaker the relationship. Second, emotional intensity among contacts. A strong tie is not only indicated by physical interaction but also emotional interaction. Third, intimacy, which is measured by the frequency of conversation of personal or secret information among contacts. If an actor talks or discusses personal matters with other, they have strong tie. Those who have weak ties usually do not talk about personal matters. Fourth, personal service. Strong tie is indicated by personal relationship, whereas the weak tie is the opposite (Eriyanto, 2014).

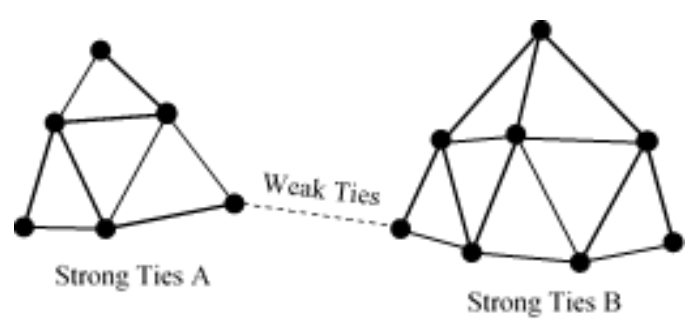

Fig. 5. A Simple Illustration the Strength of Weak Ties Theory

Granovetter (1975 \& 1983) has made several propositions concerning strong tie in triadic relationship. The first proposition is that the actors tend to account homogenity when building relation (homophile). If the two actors have already had a strong tie because they have something in common, then other actors are likely to like it as well. The second proposition is the principle of system balance. When two actors have already had strong tie, other actors who have not yet had the relation will experience dissonance in the form of inconvenience. So the actor will try to build relationship with one of or both actors. But when an actor does not admit that he has relation with other actors, according to Granovetter (1973), their relations are on a forbidden triad, like that of loveaffair. The third proposition is that weak ties always bridge (or local bridge) several strong ties in the network. Relationship between actors in different clusters is always weak ties. The fourth propositions is suggested by Easley \& Kleinberg (2010). If there are two actors with strong ties, weak ties will be formed in the relation with other actors. Thus, this bridge or local bridge is doubtless a weak tie. Granovetter (1973 \& 1983) calls it 'The Strength of Weak Ties.'

Though it is only a weak tie, it has a significant role in the social network. First, it acts as the diffusion of information, i.e. information can be spread widely to other groups through relationship between two different people coming from different clusters (weak tie). Therefore the information tend to be fresh because they come from different individuals or groups. The second is network crawling. Through the relation of weak ties, network will be spread more widely. Referring to the term proposed by Mark Granovetter (1973), Nan Lin (2001) divides social capital based on: (1) strong tie following the principles of homophile, which bonds people that is similar to them for normative or expressive objective; and (2) weak tie which unites people from different social and cultural backgrounds for instrumental objective (Field, 2008).

\section{CONCLUSION}

This paper concludes that structural holes theory is also a form of social kapital. The benefits of social capital are not only formed when trust among members of the network is high, as mentioned in network closure theory, but also when trust are low as proposed by structural holes theory. However, it depends on how the intermediary utilizes the network opportunity, i.e. the redundancy of information that exists in a relationship. The implications of both theories are proven in the strength of weak ties propositions, which essentially have combined both approaches. It means, the network advantages (information and control) will be high if an intermediary involve two ties simultaneously, weak ties and strong ties. In other words, intermediaries need to reach various kinds relationships with another different groups of networks (outgroup) in order to generate weak ties. It is important to anticipate the redundant of information that obtained from its strong ties. 
In addition, weak ties can help the intermediary gain a lot of non-redundant information that usually tends to be diverse, new, and innovative. Meanwhile, when intermediaries succeed to integrate that non-redundant information to produce a creative (good) idea, they needs to strengthen their internal ties (ingroup) in order to spread the idea to be adopted by their network members. The strong ties must be maintained to enhance mutual trust and enforce norms within the group, thereby increasing the chances of adopting the idea. In short, both theories are interdependent and complementary, so the application of structural holes theory must be collaborated with network closure theory in order to gain maximum benefit of information and control on the network. And these assumptions need should be explored and studied further in future research.

The implications of these theories are so relevant in answering the challenges of bureaucratic reform today, especially in improving the performance of public services. Because in practice, civil servants are particularly vulnerable to becoming tertius gaudens, third parties who exploit the benefits of disconnectedness of information flow between government and society. This means that, in every single aspect of public services there will always be potential for the presence of structural holes, whether intentionally or unintentionally formed. It can potentially create opportunities for corruption, collusion and nepotism activities. Such opportunities will always be there, and even bigger, although we live in the era of information disclosure. On the other hand, the presence of new media technologies can open up the transparency faucet of public information, but on the other hand it can also encourage new forms of centralized control of information that can be dominated by a handful of people to achieve certain goals.

Therefore, an internal communication audit is needed to identify the existing holes within a public service communication network. In addition, external surveillance collaboration is also required by involving various civil society, to control the implementation of a certain policy or authority. As the network closure theory assumes, closeness relationships with different groups of people can establish the enforcement of norms in a network, because each actors can keep an eye on each other. If they do it consistently, it will gradually form an autonomous collaborative surveillance mechanism that can generate a panopticon effect. Paradoxically, in order to achieve that, it is necessary to strengthen the control of information and structural autonomy by involving the role of tertius gaudens in shaping or maintaining existing holes in public service communication networks.

\section{REFERENCES}

[1] Arisanty, M. (2014). Identifikasi Ego dalam Celah Struktur pada Proses Perdamaian Konflik Etnis: Studi pada Proses Perdamaian Konflik Balinuraga antara Suku Bali Desa Balinuraga dan Suku Lampung di Lampung Selatan. Program Pascasarjana. Jakarta: Manajemen Komunikasi, Fakultas Ilmu Sosial dan Ilmu Politik Universitas Indonesia.

[2] Burt, R. S. (1995). Structural Holes: The Social Structure of Competition. Massachusetts: Harvard University Press.

[3] Burt, R. S. (2004). Structural Holes and Good Ideas. American Journal of Sociology, 349-399.

[4] Burt, R. S. (2005). Brokerage and Closure: An Introduction to Social Capital. New York: Oxford University Press.

[5] Cao, Q., \& Tian, X. (2015). The Structural Characteristics of Tourism Economic Network in Xinjiang Province. Computer and Information Science, 128-134.

[6] Dahlan, A. (1997). Pemerataan Informasi, Komunikasi dan Pembangunan. Depok: UI-Press.

[7] Eriyanto. (2014). Analisis Jaringan Komunikasi: Strategi Baru dalam Penelitian Ilmu Komunikasi dan Ilmu Sosial Lainnya. Jakarta: Prenadamedia.

[8] Field, J. (2008). Social Capital (2nd Edition). New York: Routledge.

[9] Gould, R. V., \& Fernandez, R. M. (1989). Structure of Mediation: A Formal Approach to Brokerage in Transaction Networks. Sociological Methodology, 19, 89-126.

[10] Granovetter, M. S. (1973). The Strength of Weak Ties. American Journal of Sociology, 78(6), 1360-1380.

[11] Irwansyah. (2010). Teknologi Komunikasi Sebagai Ekstensi Kekerabatan: Studi Analisis Struktur Jaringan Komunikasi Kekerabatan Berbasis Teknologi Komunikasi Telepon Seluler pada Penduduk Boro Asal Desa Pule Kabupaten Wonogiri di Sekitar Jabodetabek. Program Pascasarjana. Jakarta: Ilmu Komunikasi, Fakultas Ilmu Sosial dan Ilmu Politik Universitas Indonesia.

[12] Kurniati, A. (1998). Pola Jaringan Komunikasi Banjar di Daerah Pariwisata Bali: Studi Jaringan Komunikasi Banjar Kaja, Kelurahan Sesetan, Kecamatan Denpasar Selatan, Kotamadya Daerah Tk. II Denpasar). Jakarta: Ilmu Komunikasi, Fakultas Ilmu Sosial dan Ilmu Politik Universitas Indonesia.

[13] Liao, Y.-C., \& Phan, P. H. (2015). Internal Capabilities, External Structural Holes Network Positions, and Knowledge Creation. The Journal of Technology Transfer, 1-20. 
[14] Monge, P. R., \& Contractor, N. S. (2003). Theories of Communication Networks. New York: Oxford University Press.

[15] Rogers, E. M. (1997). A History of Communication Study: A Biographical Approach. New York: The Free Press.

[16] Toffler, A. (1980). The Third Wave: The Classic Study of Tomorrow. New York: Bantam Books.

[17] Ying, T., Norman, W. C., \& Zhou, Y. (2014). Online Networking in the Tourism Industry: A Webometrics and Hyperlink Network Analysis. Journal of Travel Research, 1-18.

\section{About the authors}

Agustinus Rusdianto Berto is a Doctoral Student of the Department of Communication, Faculty of Social and Political Sciences, Universitas Indonesia. His dissertation discusses about the structural holes of the tourism industry in Komodo National Park, Labuan Bajo. Agustinus Rusdianto Berto is the corresponding author and can be contacted at: arus.berto@gmail.com.

Ilya Revianti Sudjono Sunarwinadi is a Professor of the Department of Communication, Faculty of Social and Political Sciences, Universitas Indonesia. She has been a lecturer at the same institution since 1976. Her research interest lie in the area of intercultural communication, media and intercultural conflicts. 